\title{
The DEDO forest conservation culture a means to conserves the Ororo (Ekebergia capensis) tree.
}

\author{
getaneh Haile ${ }^{1,1}$ \\ ${ }^{1}$ Jigjiga University
}

June 8,2020

\begin{abstract}
The forest people around the world through their indigenous knowledge contribute to the sustainable management of forests. This article argues that the Sheka people in southwestern Ethiopia by their ecological knowledge, values, and spiritual use could manage the Ororo tree (Ekebergia capensis). The Ororo tree (Ekebergia capensis) is one of the most important endemic tree species in the Sheka zone southwestern Ethiopia and, at the same time, one of the most endangered species. Data collected on the indigenous ecological knowledge of the Sheka people and how the Ororo tree could be managed and conserved through the DEDO culture documented and the spiritual connection between the Ororo trees and the Sheka people traditional belief system measured. The findings revealed that through their traditional forestrelated knowledge, the Sheka people conserve and manage a single larger tree called Ororo. The Ororo tree is a special type of tree that has cultural and spiritual attachments that are presently non-existent. This unique forest conservation practice has been referred to as the DEDO culture. The culture of DEDO comes up with worshiping around the Ororo tree. Thus, the culture of DEDO played an important role in maintaining the conservation of the DEDO sacred tree (Ororo) and biodiversity therein. Over time, the DEDO sacred tree (Ororo) conservation culture has been decline, and various factors have contributed to the decline of this useful ecological knowledge.
\end{abstract}

\section{Introduction}

Recent developments in the field of traditional forest-related knowledge have led to renewed interest in the conservation, management, and sustainable use of natural resources. This interest has been increasingly recognized, documented, and utilized both in developing and developed countries (Parrotta, 2000; Parrotta \& Troper, 2012; Menzies \& Butler, 2006). The role of indigenous knowledge in forest conservation in Africa has also been recognized in recent years. Its potential contribution to Africa's ecology has not been well studied. Recently, very few studies have been conducted to depict the contribution of traditional knowledge to biodiversity, climate change, and combating desertification.

Traditional forest-related knowledge has upheld the occupations, culture, personalities, and the woodland and farming assets of the neighbourhood and indigenous networks everywhere throughout the world (Parotta and Trosper, 2012). Traditional forest-related knowledge (TFRK) is of specific significance to indigenous networks, people groups, and countries (Martinez Cobo, 1986/7). Numerous specialists have put accentuation on incorporating traditional forest-related knowledge and scientific knowledge for the protection of timberland nature forests (Baker, 1992; Michel. and Gayton, 2002).

The issue of traditional knowledge of forest management has received considerable critical attention. A good evidence of this is what Parrotta and Trosper (2012) mention. The authors viewed that traditional forest-related knowledge, innovations, and practices contribute to sustainable development in several ways. According to the authors, widely used products such as plant-based medicines and cosmetics, agricultural and 
non-wood forest products, and handicrafts are derived from traditional knowledge of forest management. He also goes on to say that most indigenous and local communities live in areas containing the vast majority of the world's forest (and agricultural) genetic resources called biodiversity hotspots. The traditional knowledge and techniques used to sustainably manage and use these genetic resources and ecosystems can provide useful insights and models for biodiversity conservation practices and policies.

Human interactions with nature have shaped both the attitudes and behaviors of people towards nature (Cristancho and Vining, 2004). Thus, every culture has a system of beliefs that guides their interactions with nature. One of the traditional forest management practices commonly found in Sheka zone is DEDO.

The Sheka people have their own knowledge and perspectives regarding the conservation and management of trees. A tree in Sheka was conserved by local belief systems called the DEDO, the tree conservation culture. The DEDO tree conservation culture serves as a spiritual purpose. Traditional tree conservation knowledge by the rural community about forest resource use, management, and conservation practice got considerable attention globally. Communities at a grass-root level who possess a wealth of indigenous knowledge about forest resource use, management, and conservation should be encouraged to maintain and pass this practical and useful knowledge to the next generation.

Traditional forest-related knowledge in forest management practices is attracting greater attention from natural resource management (NRM) because if it is combined with scientific knowledge, it can play a far greater role in sustaining biodiversity and ecosystem services as well as increase forest productivity (Becker \& Ghimire, 2003).

This study examines the types of traditional forest-related knowledge and management culture of Sheka communities inhabiting the Sheka forest. The analyses included how the role of traditional forest-related knowledge and culture and associated management practices in the conservation of forest resources. The study also examined the interdependence of the decline of traditional forest-related knowledge and forest cover change. Large tracts of dense and well-protected patches of community-owned primary forests can still be seen in many parts of the Sheka zone. This can be attributed to the traditional forest-related knowledge and management practices of the Sheka communities inhabiting the Sheka forest since time immemorial.

According to the traditional forest-related knowledge and cultural practices of the Sheka communities, the Sheka forest was conserved and managed into different types depending on their intended use. Locally, these forests are known as sacred forest (DEDO). In both Masha and Andracha woreda,a particular type of tree is managed. The sacred forest (DEDO) is frequently related to spiritual connections to the people in the village.

Methods

General Description of the Study area

The Sheka Zone is located at about $670 \mathrm{~km}$ from Addis Ababa. It is found in the South Nations Nationalities and Peoples Regional State. The Sheka zone shares boundaries with the Oromia Regional State in the North, Bench Maji Zone in the South, Gambella Regional State in the West, and Kefa Zone in the east. The total area of Sheka was 2175327 ha. Geographically, the Sheka Zone lies between $7^{\circ} 24^{\prime}-7^{\circ} 52^{\prime} \mathrm{N}$ latitude and $35^{\circ} 31^{\prime}-35^{\circ} 35^{\prime} \mathrm{E}$ longitude. The Zone has three woredas namely: Masha, Andracha, and Yeki. In the Zone, there are 56 rural and 7 urban peasant associations (Pas) in three woredas. 


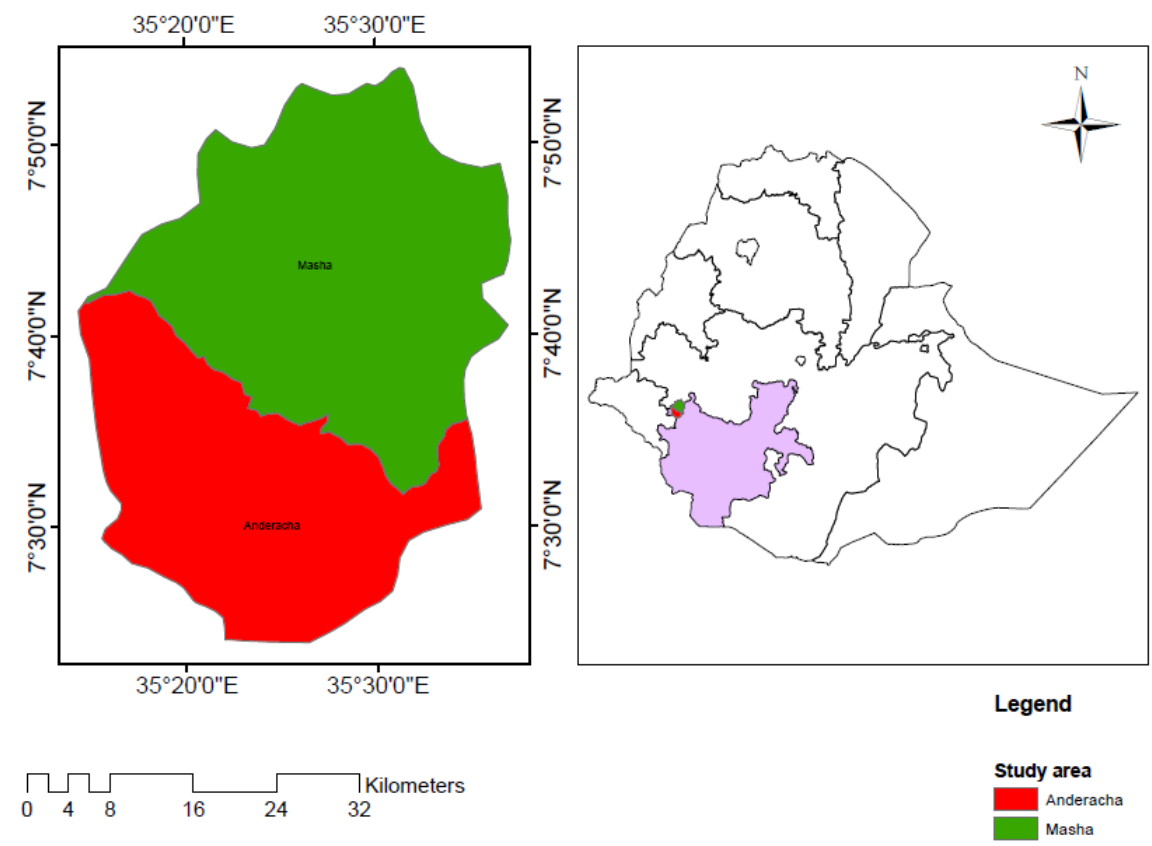

Figure 1: Map of study area

\section{Setting}

Interviews

It is believed that the place where the researcher does the interview will have an impact on the answer that he gets. Nouria Bricki and Judith Green (2002) identified three main pre-conditions for an interview setting. These include:

1. Is there enough privacy for the interviewee to feel comfortable in giving honest answers?

2. Is there too much privacy, making the interviewee uncomfortable?

3. How can you organize the space and people to make sure the interviewee is relaxed?

The settings for the interviews conducted during this study were chosen to suit the convenience of participants and to minimize interruption to their schedules. Prior to commencing data collection, the interviews were conducted in three main sites: the Sheka zone has three woreda's Yeki, Masha, and Andracha. In each woreda, there were selected research participants.

Twenty farmers were interviewed and 10 community elders for two focus group discussions for each woreda. One NGO project manager and three government officials were interviewed. Most first interviews and all second interviews with community elder's participants were conducted in their home, and focus group discussions were done at the clan leader's (Gepi tato) home on their day off from work.

Since the majority of community elders are from a rural part of the country appointment of community elders to clan leader's (Gepi tato) home was done in advance. Responsible government officials in the area of forest and rural development were willing to their office for me to conduct the sole interview. Both interview and focus group discussions were taken at weekend times for community elders, but for government official's appropriate working days were selected.

Focus group discussion

Data were collected by focus groups, one for each village, involving people crosswise over age gatherings. Gathering sizes changed from 10 to12. Six villages were purposefully selected, two from each kebele. The 
reason for the selection of the village is that (1) population size, (2) proximity to the main road (3) the presence of the sacred Ororo tree (Ekebergia capensis ).

Analysis Sociocultural (including IK and its relation to the sacred Ororo tree (Ekebergia capensis) conservation will be examined by focusing on the cultural practices of the local population. In 2007, the three study kebeles had an estimated population of 7285 (CSA, 2007). Questions will be retrospective and focus on the decline of indigenous knowledge.

The Sheka people traditional knowledge of forest includes biodiversity conservation and management of the Ororo tree. In the Ethnographic analysis of the DEDO culture the study:

1. Explain how indigenous ecological knowledge of Ororo tree could be managed and conserved through the DEDO culture.

2. Explore the spiritual connection between the Ororo trees and the Sheka people traditional belief system.

Results

Today, deforestation is one of the major environmental challenges affecting the world; however, the Sheka people through their indigenous knowledge of forest conservation strategies can sustainably manage the Sheka forest. The Sheka people have long been sustainably managing and conserving the Sheka forest by utilizing different procedures. Shockingly, these indigenous methods for normal asset administration and nearby adjustment techniques are ordinarily absent from scientific forest management and not archived. The DEDO culture demonstrates how the Sheka people through their indigenous culture can provide valuable, appropriate, and effective forest conservation strategies. Here under results of the analysis of " the DEDO culture" are explained in detail by considering key points

Table 1 Key points to consider during interviews about the sacred Ororo tree (Ekebergia capensis) and the DEDO conservation culture among interviewees in selected villages

Statement about the sacred forest (GUDO) belief

Do you believe the spiritual connection between the DEDO forest conservation culture with the Ororo tree (Ekebergia caper

Do you believe the DEDO forest conservation culture could manage and conserve the Sheka forest

Do you believe the sacred tree(DEDO) very useful for the life of the human being

Do you believe Tender an lightening will damage the villager if the Ororo tree (Ekebergia capensis) is felled

Do you believe the protection of the sacred tree(DEDO) associated with abundances of yield in the harvest season

Do you believe Cutting of the Ororo tree (Ekebergia capensis) associated with loss of life and property

Do you believe the sacred tree (Ekebergia capensis) believed to be the house of angels

Traditional sacred tree, People's beliefs, and conservation mechanisms in the study area

Six belief systems were identified, and eight conservation mechanisms observed to be in practice in the area, which were relevant to sustainable conservation and management of the Ororo tree. The sacred tree (Ekebergia capensis ) and the DEDO culture are the most common cultural institutions in all villages, and they have a direct bearing on the lives and behaviors of the people.

Table 2 Traditional sacred tree, People's beliefs, and conservation mechanisms in the study area 


\begin{tabular}{|c|c|c|c|}
\hline Cultural institution & Name of sacred tree & People's beliefs & $\begin{array}{l}\text { Conservation } \\
\text { mechanisms }\end{array}$ \\
\hline the DEDO culture & $\begin{array}{l}\text { the Ororo tree (Ekebergia } \\
\text { capensis) }\end{array}$ & $\begin{array}{l}\text { Cutting of the Ororo tree } \\
\text { (Ekebergia capensis), } \\
\text { believed to cause } \\
\text { damages and loss of life } \\
\text { and property to the } \\
\text { villagers. anyone who } \\
\text { cuts the the Ororo tree } \\
\text { (Ekebergia capensis), } \\
\text { would suffer from horrible } \\
\text { disease People worship } \\
\text { the Ororo tree (Ekebergia } \\
\text { capensis) through the } \\
\text { DEDO culture The Ororo } \\
\text { tree (Ekebergia capensis) } \\
\text { believed to be the house } \\
\text { of ghosts. Tender and } \\
\text { lightening will damage } \\
\text { the villager if the Ororo } \\
\text { tree (Ekebergia capensis) } \\
\text { are felled in the village } \\
\text { No cutting of the Ororo } \\
\text { tree (Ekebergia capensis) } \\
\text { believed to be very useful } \\
\text { for the life of the human } \\
\text { being. }\end{array}$ & $\begin{array}{l}\text { The Ororo tree } \\
\text { (Ekebergia capensis) } \\
\text { cutting restrictively } \\
\text { prohibited in the sacred } \\
\text { forest (GUDO). Felling of } \\
\text { the Ororo tree (Ekebergia } \\
\text { capensis) is restricted for } \\
\text { every individual of the } \\
\text { village the Ororo tree } \\
\text { (Ekebergia capensis) are } \\
\text { not unnecessarily felled } \\
\text { The Ororo tree } \\
\text { (Ekebergia capensis) are } \\
\text { allowed to grow freely. } \\
\text { The Ororo trees } \\
\text { (Ekebergia capensis) are } \\
\text { protected from any kinds } \\
\text { of destruction. Touching } \\
\text { of the Ororo tree } \\
\text { (Ekebergia capensis) is } \\
\text { not allowed The Ororo } \\
\text { trees (Ekebergia capensis) } \\
\text { are protected from } \\
\text { damage by wild animals. } \\
\text { Do not use any parts of } \\
\text { the Ororo tree (Ekebergia } \\
\text { capensis). }\end{array}$ \\
\hline
\end{tabular}

People's knowledge of the sacred ororo tree (Ekebergia capensis )

The vast majority of respondents $(97 \%)$ were aware of the presence of the Ororo tree (Ekebergia capensis ) and the DEDO culture in and around their village. It is found near to villages of the community. Older people ( $>55$ years of age) could more accurately describe Ororo tree and DEDO culture than younger people could, but this difference was not significant. All research participants from Masha and Anderacha woreda knew where these Ororo tree (Ekebergia capensis) stands. All of them worshiped at least once in the Ororo tree (Ekebergia capensis).

The spiritual connection between the DEDO forest conservation culture with the Ororo tree (Ekebergia capensis )

The forest people around the world through their indigenous knowledge contribute to the sustainable management of forests. The Sheka people in southwestern Ethiopia by their ecological knowledge, values, and spiritual use could manage the Ororo tree (Ekebergia capensis). The Ororo tree (Ekebergia capensis ) is one of the most important endemic tree species in the Sheka zone southwestern Ethiopia and, at the same time, one of the most endangered species. Eighty-five percent (85\%) of respondents confirmed that the sacred Ororo tree (Ekebergia capensis ) is a cultural symbol related to indigenous beliefs and signifies spiritual connections to the forestland and with Sheka people.

The Sheka people in southwestern Ethiopia had a well-defined social structure that is closely associated with forest management. Through their traditional forest-related knowledge, the Sheka people conserve and 
manage a single larger tree called Ororo. The Ororo tree is a special type of tree that has cultural and spiritual attachments that are presently non-existent. This unique forest conservation practice has been referred to as the DEDO culture. The culture of DEDO comes up with worshiping around the Ororo tree.

Participants of FGD both in Masha and Anderacha woreda explained the historical connection of the Ororo tree with the DEDO culture. "According to Sheka people traditional belief once upon the time in the history of Sheka people, there was a drought for a long period. The drought had damaged all trees except the Ororo tree. The survival of Ororo trees from the rest made the Ororo tree as cultural symbols and related to the indigenous belief that signifies spiritual connections to God (Shemayo tato).

During drought time in the history of Sheka, there is a saying that the angel of GOD rest under the Ororo tree because of this if people pray or worship under the Ororo tree, the angel of God will take their prayer to God. As many Sheka people do believe that the angel of GOD rest under the Ororo tree because of this if people pray or worship under the Ororo tree, the angel of God will take their prayer to God. Because of the spiritual connection to this particular tree of Ororo, the Ororo tree will not be used for any other economic activities like the production of honey and other domestic uses. Therefore, the conservation of the Ororo tree has a direct spiritual connection and has contributed to the conservation and protection of the Ororo tree.

The Ororo tree and DEDO cultural ceremonies

Overall, $86 \%$ of respondents "agreed" with the Statement that the ororo sacred tree and the DEDO culture are used by sheka people as cultural symbols related to indigenous beliefs and signify spiritual connections to the forests" (Table 1). The belief that tender and lightening will damage the villager if the sacred Ororo tree (Ekebergia capensis) are felled in the village was very popular-86\% "agree" response (Table 1).

The DEDO culture was celebrated once in a year in the months of December around Christmas as Thanksgiving Day. Offerings were made each year at this time. One of the key informants in Gecha Town explains how the DEDO culture was celebrated each year. During the months of December, when yields were harvested, people in the village were gathered together to celebrate Thanksgiving Day around the DEDO sacred tree (Ororo) under the advice of clan leaders (Gebi tato). The DEDO sacred tree (Ororo) culture was celebrated near to village according to their clan and the clan leaders (Gebi tato) as "traditional forest-related knowledge experts," i.e., persons recognized by the Sheka community were responsible for making and enforcing rules related to the DEDO cultural ceremony.

The purpose of the offering was to giving thanks to GOD (Shemayo tato) for the harvest season. After giving thanks to GOD (Shemayo tato) for the good harvest of the season, the Sheka people pray to GOD (Shemayo tato) the next season to be a season of health, fortunes and good harvest. Therefore, the DEDO sacred tree (Ororo) was believed to bring health, fortune, and good harvest.

The other key informant in his description the way the DEDO culture was celebrated he cogently explained that the DEDO culture was celebrated each year seven days before Christ-mas. local cereals (Teff) were harvested around Christ-mas time and for the DEDO celebration foods and alcohol, drinks were mostly prepared from local cereals called Teff. Wednesdays is a day used for the celebration of DEDO culture. The aim of the DEDO culture was praying to GOD (Shemayo tato) for the next good harvest and for the health of the people.

Another relationship between the DEDO culture and the Sheka people is that long years before the Sheka people did not have health facilities access because of this many young and adult parts of the population died at an early age. In fear of this killing disease, all the village members gathered around the Ororo tree and celebrated the culture of DEDO and pray to GOD (Shemayo tato) about their health. Therefore, the Ororo tree is believed to bring health to the Sheka people. According to the Sheka belief, the DEDO tree is untouchable. No one was allowed to cut the Ororo tree. It is conserved and protected well for centuries for spiritual purposes. 
The interview and FGD results provide useful examples of the DEDO sacred tree conservation culture and traditional forest-related knowledge possessed by the Sheka people. As an informant recalled:

In the past, the Sheka people have held ceremonies to pray for a successful harvest season and express their thanks to GOD (Shemayo tato). The Sheka people participate in rituals for GOD (Shemayo tato) on the month of December, according to the Ethiopian calendar each year. They collectively participate in traditional rituals of food preparation and beverages (made from Teff) before they put the harvest into the granary. These rituals play an important role in encouraging relationships between members of the community.

Cutting of Ororo tree (Ekebergia capensis )

The majority of respondents (80\%) said they the DEDO tree conservation culture could manage and conserve the Sheka forest. Spiritual connections and beliefs were the main reasons why people worship around the sacred Ororo tree (Ekebergia capensis ). The protection of the sacred Ororo tree (Ekebergia capensis) enables the conservation of natural forests from earlier anthropogenic disturbances, allowing trees and other plant species to reproduce. The entire the sacred Ororo tree (Ekebergia capensis ) was put under the imposition of local cultural beliefs.

The Sheka people considered the Ororo tree to be sacred and believed to protect the village from natural calamities, famine, and diseases Therefore the culture of DEDO sacred tree (Ororo) contribute positively to the conservation of Ororo tree. Access to DEDO sacred tree (Ororo) is forbidden by Sheka culture, and the DEDO sacred tree (Ororo) is untouchable and no person is allowed to cut or make use of the DEDO sacred tree (Ororo) for another purpose. Therefore, the DEDO sacred tree (Ororo) is considered to be the king of the trees in the village.

The DEDO sacred tree (Ororo) once exists in every village as spiritual or sacred sites. These trees are usually very tall and long. The Sheka believe that these trees can provide safety, fortune, and good harvests for their villages. According to one of the key informants in Masha woreda, Yepo Kebele the clan leader (Gebi tato) said, "no one is allowed to cut down these trees, and any person who cuts these trees will be punished because of the curse that is associated with indigenous belief.

According to the research participant, there was a true story about a person who violated the culture of DEDO. In Masha woreda, there was a person who cut down a DEDO sacred tree (Ororo): he was dead by thunder and lightning immediately. The above quote about a person reminds that the Sheka people represent the DEDO sacred tree (Ororo) has direct connections to their GOD (Shemayo tato). According to Sheka traditional belief, if any person who cuts down the DEDO sacred tree (Ororo) rain will become abnormal, usually resulting in floods. There is a similar story in Anderacha woreda about the death of a young man after he cut down the DEDO sacred tree (Ororo) he died consequently.

Even though the younger generation has limited knowledge of the DEDO sacred tree (Ororo), all Clan leaders (Gebi tato), and older men who participated in this research work agreed that they firmly believe in the supernatural meanings attached to the DEDO sacred tree (Ororo). All twenty research participants from the study area knew how and where the DEDO sacred tree (Ororo) conservation culture was practiced. All of them had worshiped in the DEDO sacred tree (Ororo) for many years in their lifetime.

According to research participants from the community elderly: no one dares to touch the DEDO sacred Ororo tree. According to the research participant (KI-9, 28 Jan 2016 Masha Town), those who touched the DEDO sacred tree (Ororo) would be cursed and died. During the interview, both Clan leaders (Gebi tato) and older men told us that before 30 years ago, the DEDO culture was a very common traditional belief in almost every village in the Sheka zone. However, this tree conservation cultural has gradually disappeared, particularly in recent decades.

Discussion

Over the years, there have been increasing concerns about the decline of traditional forest-related knowl- 
edge, leading to calls for effective responses to ensure forest sustainability (Parrotta and Agnoletti, 2006). This concern has been increasingly recognized, documented, and utilized both in developing and developed countries (Berkes et al., 2000; Bürgi et al. 2013; Ramakrishna,2007) In Ethiopia, forest conservation and management range from state-owned forest to privately owned forests. There was no room for traditional forest conservation and management approaches. The first approach such as state-owned forest management (Dessalegn Rahmato, 2001; FDRE, 2007). The latter approach advocates privately owned forests. However, it has been argued that both of this approach alone often fails biodiversity conservation unless it is supported by traditional forest conservation and management approaches.

The role of indigenous knowledge in forest conservation in Africa has also been recognized in recent years. Its potential contribution to Africa's ecology has not been well studied. Recently, very few studies have been conducted to depict the contribution of traditional knowledge to biodiversity, climate change, and combating desertification. Traditional forest-related knowledge has upheld the occupations, culture, personalities, and the woodland and farming assets of the neighbourhood and indigenous networks everywhere throughout the world (Parotta and Trosper, 2012). Traditional forest-related knowledge (TFRK) is of specific significance to indigenous networks, people groups, and countries (Michel H \& Gayton DV 2002). Numerous specialists have put accentuation on incorporating traditional forest-related knowledge and scientific knowledge for the protection of timberland nature forests (Michel H \& Gayton DV 2002; Menzies, CR, \& Butler, C 2006).

The negative attitude towards traditional forest conservation culture can undermine local, national, regional, and international conservation initiatives. Gadgil et al. 1993, Gadgil M, Berkes F 1991, and Gadgil M 1985 argue that traditional forest conservation culture plays a pivotal role in forest conservation and management. Therefore, it is crucial to recognize and incorporate the importance of such conservation culture into forest resource management plans. The recognition of traditional forest conservation culture in forest management will not only affect population viability but may also have broader environmental impacts. The recognition of traditional forest conservation culture is also necessary for ensuring that forest management policies are both effective and sensitive to local realities (Gupta, H.K. 2005 and Gupta, H.K. 2006). In this regard, it is important to continuously conduct studies on forest management to inform area-specific policies as the conservation culture toward forest often differs from one setting to the other. Few studies to understand traditional forest conservation culture in forests are situated in Ethiopia (Desalegn Fufa, 2013). This is despite the fact that Ethiopia is wealthy in its flora, and it is evaluated to harbor more than 6000 types of higher plants, of which around 125 are endemic (Ib Frus 1982), requiring their protection and conservation.

A common thread in developing and applying conservation policies requires gaining the support of traditional forest conservation cultures and engaging these conservation culture in collaborative conservation efforts (Gadgil et al. 1993; Gadgil M, Berkes F 1991; Gadgil, M. 1985; Gupta, H.K. 2005, Gupta, H.K. 2006). Therefore, studies in traditional forest conservation culture contribute to the development of effective forest conservation and management policies that are sensitive and relevant to local conditions and the degree to which local communities are willing to coexist with forest resources (Gadgil et al. 1993; Gadgil M, Berkes F 1991, and Gadgil, M. 1985).

Traditional forest conservation culture in sub-Saharan Africa has vast indigenous knowledge that has kept its forest ecosystem pristine and protected for decades (Mumma, A. 1999, and Tengeza A, 2000). Other than the spiritual attachment to their environment, rural communities were historically dependent on forest resources for their livelihoods (FAO 2014). However, the introduction of state-sponsored deforestation and markets influencing agricultural expansion in the African continent resulted in centralized control over natural resources by state, which resulted in the taking away of decision-making concerning forest resources from rural communities(GRAIN 2008, Cotula et al. 2009;Deininger and Byerlee, 2011). Consequently, rural communities became passive observers of the forest resources around them. The state forest law of the southern nations, nationalities, and people's region (SNNPR) put community forest under state forest.

The government of Ethiopia adopted state forest laws that put community forest under state forest; therefore, these laws limit the local population forest resources utilization and introduced a total ban on using forest at one point (Dessalegn,2001). This state of forest conservation practice is the detriment of local communities. 
As a result, there is an ongoing conflict between the state and the local people in southwestern Ethiopia, which is attributable to the hostile relationship between conservation and livelihoods of communities living adjacent to and within the sheka forest.

To our knowledge, this is the first study to analyze traditional forest conservation culture of forest, using DEDO tree conservation culture as a proxy, how the Sheka people through their indigenous culture can provide valuable, appropriate, and effective forest conservation strategies. The analysis is important in providing insights on how tree conservation culture and current practices may influence forest sustainability and its supporting institutions. This is crucial for rethinking the design of conservation policies that allow for effective management and planning, sensitive to local realities. Specifically, this study analyzes the spiritual connection between Ororo trees and the Sheka people traditional belief system could be managed and conserved through the DEDO culture.

Conclusion

The culture of DEDO played an important role in maintaining the conservation of the DEDO sacred tree (Ororo) and biodiversity therein. Over time, the DEDO sacred tree (Ororo) conservation culture has been declining and various factors have contributed to the declining of this useful ecological knowledge. These include anthropogenic factors, modernization, and religion.

\section{Acknowledgement}

The authors are grateful to Prof. Teshome Soromessa, a professor of environmental science. Center for Environmental Science, College of Natural and Computational Sciences Addis Ababa University, for providing the necessary facilities to carry out the present work. The authors also acknowledge the wise people of sheka people for providing information on various IKS-related conservation of tree and forest resources.

Data Availability statement: data publicly available in a relevant repository such as Dryad

\section{Declarations}

Ethics approval and consent to participate: The study was approved by the CAES Research Ethics Review Committee at the University of South Africa (UNISA) on 10/02/2015 with Ref \#: 2015/02/004, name of applicant: Mr GH Shoddo, student \#:53342852. Decision: Ethics Approval, Supervisor: Prof Teshome Soromessa Aurgessa, Qualification: Postgraduate degree.

Consent for publication: "Not applicable".

Availability of data and materials: All data generated or analyzed during this study are included in this published article (see literature cited).

Competing interests: The authors declare that they have no competing interests.

Reference

Becker CD Ghimire K 2003: Synergy between traditional ecological knowledge and conservation science support forest preservation in Ecuador. Retrieve from http://www.consecol.org/vol18/isi1/art1/

Berkes, F.; Colding, J.; Folke, C 2000. Rediscovery of traditional ecological knowledge as adaptive management. Ecol. Appl. 2000, 10, 1251-1262

Bürgi, F.; Gimmi, U.; Stuber, M 2013. Assessing traditional knowledge on forest uses to understand forest ecosystem dynamics. For. Ecol. Manag. 2013, 289, 115-122.

Central Statistical Agency 2007: population and housing census of Ethiopia. Addis Ababa, Ethiopia.

Cotula L, Vermeulen S, Leonard R, \& Keeley J 2009: Land Grab or Development Opportunity? Agricultural Investment and International Land Deals in Africa. IIED, 2009. 
Cristancho S \& Vining J 2004: Reciprocity as Principled Argument: The Ethics of Human-Nature Interactions for the Letuama. Department of Natural Resources and Environmental science.

Deininger K \& Byerlee D 2010: Rising global interest in farmland: Can it yield sustainable and equitable benefits? Washington: World Bank.

Desalegn Fufa 2013: Indigenous Knowledge of Oromo on Conservation of Forests and its Implications to Curriculum Development: the Case of the Guji Oromo

Dessalegn Rahmato (2001), Environmental change and state policy in Ethiopia: lesson from past experience, FSS monograph series, no. 2 Addis Ababa: Forum for Social Studies

Federal Democratic Republic of Ethiopia (FDRE) (2007). Forest development, conservation and utilization proclamation no. 542/2007. Negarit Gazetta No 56. Addis Ababa, Ethiopia. pp. 1-14.

Gadgil M, Berkes F 1991. Traditional resource management systems. Resource Management and Optimization 18: 127-141

Gadgil M, F Berkes and C Folke 1993. Indigenous Knowledge for biodiversity conservation .Ambio 22:151-6

Gadgil, M. 1985. 'Social Restraints on Resource Utilization: The Indian Experience'. In J.A. McNeely and D. Pitt, eds., Culture and Conservation: The Human Dimension in Environmental Planning, Croom Helm, Dublin

GRAIN 2008: Seized! The 2008 land grab for food and financial security. GRAIN Briefing October 2008.

Gupta, H.K. 2005. Conservation and traditional knowledge systems: a case study of sacred forest groves of Himachal Himalays, India. Paper presented at USEFI and IIHS workshop on Conserving Hill and Mountain Ecology, Shimla, August 24-26, 2005.

Gupta, H.K. 2006. Joint Forest Management: Policy, Participation and Practices in India. International Book Distributors, Dehradun, India. 400 pp ICSU, 2002. Traditional Knowledge and Sustainable development.ICSU Series on Science for Sustainable Development No.4 International Council for Science, Paris.24 p. Available from:http//www.icsu.org/.

Ib Frus 1982: Studies in the flora and vegetation of southwest Ethiopia. Institute of systematic botany university of Copenhagen K Denmark.

Martinez Cobo J1986/7: Study of the problem of discrimination against indigenous populations. UN Doc. E/CN.4/Sub.2/1986/7 and Add. 1-4 Available viahttp://www.un.org/esa/socdev/unpfii/en/spdaip.html.

Menzies, CR, \& Butler, C 2006: Understanding ecological knowledge. In C. R. Menzies (Ed.), Traditional ecological knowledge and Natural Resource Management Lincoln: University of Nebraska Press.

Michel H \& Gayton DV 2002: Linking Indigenous peoples' knowledge and Western science in natural resource management: A dialogue. B.C. Journal of Ecosystems and Management, 2(2), 1-12.

Michel H \& Gayton DV 2002: Linking Indigenous Peoples' Knowledge and Western Science in natural resource management: A Dialogue. B.C. Journal of Ecosystems and Management, 2(2), 1-12.

Mumma, A. (1999), 'Legal Aspects of Cultural Landscapes Protection in Africa'. in: M. Rossler and G. Saouma-Forero (eds.), The World Heritage Convention and Cultural Landscapes in Africa, Expert Meeting - Tiwi, Kenya, 9-14 March 1999. UNESCO

Nouria Bricki, Judith Green 2002: A Guide to Using Qualitative Research Methodology. 2002 MSF Field Research.

Parrotta, J.A. 2000. Catalysing natural forest restoration on degrades tropical landscapes. Pages 45-54 in S. Elliot, J. Kerby, D. Blakesley,K. Hardwick, K. Woods and V. Anusarnsunthorn, editors. Forest restoration 
for wildlife conservation. International Tropical Timber Organization and the Forest Restoration Research Unit, Chiang Mai University, Chiang Mai, Thailand.

Parrotta, J.A., Agnoletti, M., 2007. Traditional Knowledge, Cultural Heritage and Sustainable Forest Management. Forest Ecology and Management 249, 1-139.

Parrotta, J.A., Agnoletti, M., Johann, E. (Eds.), 2006. Cultural heritage and sustainable forest management: the role of traditional knowledge. Proceedings of an International Conference held in Florence, Italy, June 8-11, 2006. Warsaw, Poland: Ministerial Conference on the Protection of Forests in Europe, Liaison Unit Warsaw, Vol. 2. Available from: http://www.iufro.org/ science/task-forces/traditional-forest-knowledge/

Parrotta, JA \& Trosper, RL. 2012. Traditional Forest-Related Knowledge: Sustaining Communities, Ecosystems and Biocultural Diversity. U.S. Forest Service Research and Development Branch and Aerican Indian Studies The University of Arizona.

Ramakrishna, P.S 2007. Traditional forest knowledge and sustainable forestry: A north-east India perspective. For. Ecol. Manag. 2007, 249, 91-99.

Tengeza A, 2000, Traditional and Cultural Control of Indigenous Forest Resources: Kaya Rabai By-laws. Internal NMK/CFCU Note

\section{Hosted file}

figure.docx available at https://authorea.com/users/329284/articles/457270-the-dedo-forestconservation-culture-a-means-to-conserves-the-ororo-ekebergia-capensis-tree 